NBER Working Paper Series

OPTIMAL TAX THEORY, ECONOMETRIC EVIDENCE,
AND TAX POLICY

Michael J. Boskin

Working Paper No. 152

CENTER FOR ECONOMIC ANALYSIS OF HUMAN BEHAVIOR AND SOCIAL INSTITUTIONS

National Bureau of Economic Research, Inc.

204 Junipero Serra Boulevard, Stanford, CA 94305

October 1976

Preliminary; not for quotation.

NBER working papers are distributed informally and in limited number for coments only. They should not be quoted without written permission of the author.

This report has not undergone the review accorded official NBER publications; in particular, it has not yet been submitted for approval by the Board of Directors.

This research was supported by a contract with NBER from the Office of Tax Analysis, U.S. Treasury Department (No. TO-76-13; OS 612). 


\section{Optimal Tax Theory, Econometric Evidence, and Tax Policy *}

by

Michael J. Boskin**

\section{Introduction}

A renewed interest in the theory of optimal taxation has emerged in recent years. The theory of optimal taxation generally has followed two disparate paths: the theory of optimal commodity (or indirect) taxation and the theory of optimal income (or direct) taxation. Only occasionally have attempts been made to integrate or compare these two approaches. While each has an interesting history in economics, much important work is of recent origin and, I shall argue below, much remains to be done if we are to use optimal tax theory as a guide to the formulation of tax policy.

The major achievement of the theories of optimal income and commodity taxation is the derivation, under a series of well-specified assumptions, of rules which the tax system must follow if it is to maximize (alternative representation of) social welfare. Not surprisingly, these rules provide formulae for optimal rates of tax on different commodities or different levels of income which are functions of several key parameters in economics: price (and income) elasticities of demand, the wage elasticity of labor supply, and the interest elasticity of saving, among others.

\footnotetext{
*This paper was presented at the International Economic Association Conference on "Contributions of Econometrics to Public Policy," Urbino, Italy, September 1976. I wish to thank Partha DasGupta and the other conference participants for useful suggestions.

${ }^{* *}$ Stanford University and NBER.
} 
It is thus obvious that estimates of these parameters play a crucial role in both the analysis and potential implementation of optimal tax theory. First, such estimates are necessary inputs in the provision of numerical examples of the optimal tax formulae. The range of estimates actually employed in analytical studies of optimal taxation is quite wide. Second, the incorporation of optimal tax theory into actual tax policy depends upon rather precise and stable estimates of these parameters. While we may write interesting papers detailing the optimal tax rates for several alternative plausible parameter values, the fiscal authorities, of course, must develop and implement a unique set of rates. While the rates can, do, and should change occasionally, we would hardly endear ourselves to elther taxpayers or tax collectors if we proposed changing the rate with each new empirical study appearing, say, in Econometrica!

Fortunately, a renewed interest in obtaining improved econometric estimates of these parameters has occurred simultaneously with the renewed theoretical interest in optimal tax rules. The availability of new data, the development of new estimation methods and a renewed interest in the practical policy implications of the theoretical propositions of optimal tax theory have produced new and substantially improved econometric estimates of some of the most important determinants of optimal tax rates. Combined with some of the more robust propositions of optimal tax theory, this new and improved econometric evidence has important implications for tax policy.

The purpose of this paper is to provide a progress report on the issue of the implications of optimal tax theory and recent econometric evidence for tax policy. Toward this end, Section 2 provides a brief and of ten 
heuristic summary of the major results of optimal tax theory. I discuss the famous Ramsey Rule and inverse elasticity formula for optimal commodity taxation. I also discuss the application of this analysis to the question of the desirability of a consumption rather than an income tax. Finally, I present the implications of the analysis of optimal direct taxation. These analyses highlight the Importance of labor supply and saving elasticities.

Section 3 reports the results of some recent econometric studies of saving and labor supply. Particular attention is paid to relating the econometric evidence to the theoretical constructs of the optimal tax models. For example, I discuss in detail the problem in going from estimates of the relation between hours of work and net wage rates to the concept appropriate for the optimal tax problem: the wage elasticity of labor supply in the envelope sense, subsuming effort and human investment. I also discuss recent attempts to analyze tax disincentives to saving. In reporting a brief summary of recent econometric evidence, I must, of course, exercise my (subjective) evaluation of sometimes conflicting studies. I shall also take the liberty of relying upon my comparative advantage and draw heavily upon my own work.

Finally, Section 4 outlines the implications of the combined theory and econometric evidence for tax policy. My conclusion is that on the one hand considerable progress has been made on several basic issues; these include the choice between consumption and income as the basis for direct taxation; the desirability of eliminating the practice of income splitting and using different rate schedules for primary and secondary earners in 
the family; and the desirability of avoiding extremely high marginal tax rates on highly productive groups making up a significant fraction of the labor force.

On the other hand, much work remains to be done before optimal tax theory can serve as anything more than a very rough general guide to tax policy. First, additional theoretical work to examine the robustness of the results to alternative specifications is desirable. Second, considerably more econometric evidence is necessary before we have enough confidence In the precision and stability of the estimates of the relevant parameters to progress beyond several broad generalization to a more precise specification of the tax structure. 


\section{The Theory of Optimal Taxation}

The debate over desirable properties of taxes no doubt commenced when the first (probably 1mplicit) taxes were levied; in any event, it continues unabated to this day. We are all familiar with Adam Smith's four canons of taxation and their modern counterparts, such as horizontal equity, ability to pay, equal sacrifice, etc. The more rigorous and prectse analysis of taxation starts with Dupult [1854] and Edgeworth [1897], Includes Important contributions by Ramsey [1927], Pigou [1947], Hotelling [1937] Boiteux [1956] and Harberger [1964] and is currently reemerging in the work of a whole generation of public financiers. The utlitarlan approach to which I refer has been applied to a wide varlety of problems, both in an out of public finance. Its unifying theme is the study of how to achieve certain goals (raising revenues, for instance) via public policies (e.g., taxes) in such a way as to maximize, or at least improve, social welfare (which in turn depends upon the welfare of individuals) subject to a model of the economy (e.g., the behavior of consumers).

This approach to public finance problems has been applied to such diverse issues as the desirability of housing subsidies (Atkinson and Stiglitz [1976]), public utility pricing (Mohring [1973]), congestion tolls (Marchand [1971]), optimal indirect taxation (Diamond and Mirrlees [1971]), and tax expenditures (Feldstein [1975]). A series of recent papers attempt to relax some of the more restrictive assumptions of the theory, although generally at the expense of considerably complicating the optimal tax rules. Useful surveys of the area may be found in Sandmo [1976] and Atkinson and Stiglitz [1972]; an interesting history of the development of this 1ine of thought may be found in Baumol and Bradford [1970]. 
My purpose here is to present a brief heuristic introduction to the area and to discuss the applications of the theory to three basic concerns of tax policy: the choice between income and consumption as a tax base, the tax treatment of the family, and the desirability of highly progressive income tax rate schedules.

Let us start by Imagining the simplest possible economy: consumers have identical preferences and endowments so distributional consideration may be 1gnored, and we may proceed as if we have one consumer. The consumer's preferences are represented by a utility function of the usual sort,

$$
U=U\left(x_{1}, \ldots, x_{n}\right)
$$

where $x_{1}, \ldots, x_{n}$ 'are the $n$ goods produced and consumed in this economy. For convenfence, we take $X_{l}$ to be lelsure. Taking leisure as numéraire, the government seeks to collect a given amount, say $T$, in taxes. Hence,

$$
\stackrel{n}{\Sigma}=2_{1}^{n} x_{1}=T
$$

where $t_{1} 1$ the tax rate on commodity 1 . We shall further assume that producer prices are fixed (the assumption of constant returns to scale is all that is necessary). Thus $t_{1}$ is the difference between consumer prices $p_{1}$ and producer prices $q_{1}$. The problem for the fiscal authorities is to maximize (1) subject to (2). The first order conditions are 


$$
\begin{array}{r}
\sum_{1=1}^{n} \frac{\partial U}{\partial x_{i}} \cdot \frac{\partial x_{1}}{\partial t_{k}}+\mu\left(\sum_{1=2}^{n} t_{i} \frac{\partial x_{i}}{\partial t_{k}}+x_{k}\right)=0 \\
k=2, \ldots, n
\end{array}
$$

Substituting from the individual's first-order conditions for utility maximization $\left(U_{i}=\lambda P_{i}\right.$ for all 1$)$ and from the budget constraint, we have

$$
\Sigma t_{1} \frac{\partial x_{1}}{\partial t_{k}}=\frac{\lambda-\mu}{\mu} x_{k}=\gamma x_{k} \quad k=2, \ldots, n
$$

Using the slutsky equation and the symmetry of pure substitution effects, we have

$$
\frac{\left.\sum_{1=2}^{n} t_{i} s_{k i}\right)}{x_{k}}=\gamma+\sum_{i=2}^{n} t_{i} \frac{\partial x}{\partial I} i \quad k=2, \ldots, n
$$

where I is exogenous income. ${ }^{1}$

This equation yields the famous Ramsey rule: the proportionate reduction in compensated demand should be equal for all comodities (the righthand side is independent of $\mathrm{k}$ )!

As Sandmo [1976] and others have noted, this result is a particularly vivid contrast to the common, but incorrect, supposition that an equi-proportionate change in all prices (e.g., uniform commodity taxation) is desirable.

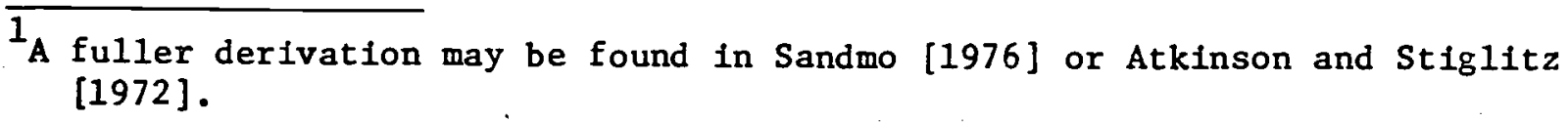


A heuristic, but more direct, derivation of the equal proportionate reduction in demand rule which $I$ have found useful in teaching undergraduates (and which I owe to Eytan Sheshinsk1) starts with the usual partial equilibrium formula for the deadweight loss associated with a tax Induced price distortion:

$$
\text { DWL }=\frac{1}{2} t_{1} \Delta x_{1}
$$

It is clear that efficiency requires that the (I suppress marginal) deadweight loss per dollar of tax revenue be equal for all commodities, i.e.,

$$
\frac{t_{1} \Delta x_{1}}{t_{1} x_{1}}=c
$$

i.e.,

$$
\frac{\Delta \mathrm{X}_{1}}{\mathrm{X}_{1}}=\mathrm{C}
$$

In general, of course, the structure of optimal taxes depends upon the entire set of own and cross price elasticlties of demand. In a model in which we allowed for many goods (Including goods at different times and locations), the informational requirements for implementing such formulae are prohibitive (see Hahn [1973]). Fortunately, In practice tax rates are generally levied by commodity groups. Such aggregation sharply dimin1shes the econometric information required (1.e., we are allowed certain separability restrictions). Further, for several interesting problems, 
we can reduce our search to information on a very small number of key parameters.

Consider, for example, the 1ssue of the desirability of uniform taxation of commodities. When is uniform taxation by a uniform VAT (or consumption tax) preferable to differential excise taxation? First, if labor is In completely inelastic supply (perfectly inelastic demand for leisure), ${ }^{2}$ it is optimal to tax only labor. In a world where only efficlency matters, there is no deadweight loss caused by a tax on a commodity in perfectly inelastic demand. The same change in relative prices (between lelsure and all other commodities; the relative prices of consumer goods remaining unchanged) may be obtalned with uniform commodity taxation. ${ }^{3}$

Hence, in this special case, the optimal structure of taxes on all commodities is found in the estimation of just a labor supply function (which proved to be perfectly inelastic).

More generally, the optimal tax rates are related to demand elasticities. Indeed, when cross-elasticities are negligible, ${ }^{4}$ the set of equations (5) reduces to

$$
\frac{t}{P_{1}} \cong \frac{\gamma}{\epsilon_{k k}}, \quad k=2, \ldots, n
$$

\footnotetext{
2 The issue is whether the untaxed commodity (or commoditles) are in complete1y inelastic demand. Since leisure - or rather time spent outside the market, Including work in the home - is in practice by far the most important such commodity, we focus on labor supply in the discussion.

3 The same result obtains when utility is separable between leisure and other goods and preferences for consumer goods are homothetic.

${ }^{4}$ This proposition is sometimes claimed to demonstrate that when all crosselasticitles are zero, commodities should be taxed in inverse proportion to their demand elasticitles. Of course, if all cross elasticities are zero, all own elasticities must be unity and uniform taxation is optimal.
} 
where $\varepsilon_{k k}$ is the own price elasticity of demand. Thus, when we can safely ignore cross-elasticities, commodities should be taxed inversely to their demand elasticities. 5 other things constant, it is inefficient to tax heavily goods with large demand elasticities.

The foregoing may be applied to the cholce between income and consumption taxation. While many other features of both each of the taxes and the economy affect such a decision, a major concern is the relative elasticities of labor supply and saving. If labor is in completely inelastic supply, it is optimal to tax labor income only (as noted above). Thus, a pure consumption tax is optimal in this case. ${ }^{6}$ If consumption is unaffected by Income (or interest income) taxation, it is optimal to tax only capital income (if sufficient revenue can be ralsed). If both labor and capital are In perfectly inelastic supply, any combination of labor and capital income taxes is optimal.

In the more realistic case of some elasticity of both factor supplies, the optimal tax structure is a mix of taxes on capital and labor income, with a higher tax rate on the factor with the lower supply elasticity. 7 Hence, once again, the implications of optimal tax theory for this important 1ssue of tax policy depends upon (econometric) estimates of labor supply and consumption functions!

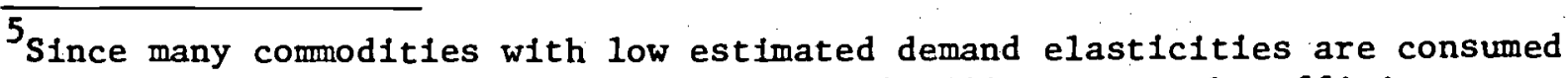
disproportionately by the poor, this rule illustrates the efficiencyequity tradeoff. Sandmo [1976] discusses approaches to this problem in more detall.

${ }^{6}$ Actually, all that is required for a tax only on labor income to be optimal is that utility be separable between leisure (at each point in time) and consumption.

7Feldstein [1977] presents a thorough analysis of this problem.
} 
As a special case of the analysis discussed above, consider the problem of how to tax families in which there are two potential earners (e.g., a husband and wife). The family's utility depends upon the consumption of goods and the leisure of each potential worker:

$$
\mathrm{U}=\mathrm{U}\left(\mathrm{C}, \mathrm{L}_{\mathrm{H}}, \mathrm{L}_{\mathrm{W}}\right)
$$

The government seeks to raise a given revenue and can tax the earnings of the husband and the wife. Under what conditions should it tax them at the same rate (e.g., as occurs under the income splitting provision, or joint return schedule, available in many countries)? Indeed, should the government attempt to tax the leisure of one of the earners via a wage subsidy, while taxing the labor supply (via an earnings or payroll tax) of the other? I have elsewhere (Boskin [1973]) analyzed this problem in detail.

The point here is that the solution depends upon the own and cross substitution effects on the labor supply of husbands and wives.

Thus, once again, the optimal tax framework reveals that the answer to a central issue of tax policy depends heavily upon estimates of own and cross wage elasticities of labor supply (of husbands and wives).

While the tradeoff between efficiency and equity can be explored in the optimal indirect tax context (see Atkinson and Stiglitz [1976]), we shall not do so here. We turn instead to the analysis of optimal direct taxation. Since it is feasible via direct taxation to levy taxes on individuals or families at different rates, such taxes are a major potential instrument of redistribution policy. 
The earliest rigorous analysis of optimal direct taxation was that of Edgeworth. He argued that if all Individuals have Identical declinIng marginal utility of income functions, the maximization of the sum of utilities (his measure of social welfare) required equalization of income! of course, this analysis ignores the potential disincentives to supply labor and save created by extremely high tax rates. Incredibly, the optimal tax problem was not analyzed with the utilitarian approach incorporating disincentive effects until quite recently. Starting with a remarkable paper by Mirrlees [1971], a series of papers has analyzed the income tax rate structure which maximizes soclal welfare subject to a government revenue requirement, a skill distribution, individual preferences for income and letsure (more generally producing income versus not producing income, e.g., supplying labor, saving, educational investment, etc.), and production posstbilities. Mirrlees' surprising result is that for a utilitarian social welfare function (the sum of utilities), a Pareto or log normal skill distribution, and elasticity of substitution between goods and leisure of unity (1.e., a very elastic labor supply), the optimal tax rates are quite low and actually decline over some income ranges; rather little redistribution Is optimal under Mirrlees' specification.

A varlety of authors have extended Mirrlees' analysis to consider alternative soclal welfare functions, the endogeneity of wage rates, and alternative skill distributions and labor supply elasticities. In general, the optimal marginal tax rates, on different income classes, depend upon the social welfare function, ability or productivity, the density of the group in the population, and the elasticity of labor supply. ${ }^{8}$ Stern [1976]

\footnotetext{
$\overline{8}$ See Stern [1976] for a survey of some of the more important papers.
} 
has demonstrated the crucial role of labor supply elasticities. The larger is the elasticity of labor supply, the lower the optimal tax rate. Further, since the models are generally atemporal, they may be reinterpreted as applying to an entire lifetime. Hence, the sensitivity of saving and human Investment to taxes also are important. The larger are the tax disincentives to produce income in the market (via hours of work effort, human investment and saving), the lower are the optimal tax rates; and if these elasticities vary in the population, ceteris paribus, the rates should be higher in those Income groups with the lower elasticities.

The generic optimal income tax problem may be analyzed as follows (I owe some of these points to Partha Das Gupta): Individuals differ in "ability" which we Index by $\theta ; g(\theta)$ is the probability density of $\theta$, i.e., $f g(\theta) d \theta=1$. Utility depends upon consumption of goods and leisure:

$$
\mathbf{U}=\mathbf{U}\left(\mathrm{C}_{\theta}, \ell_{\theta}\right)
$$

where $C_{\theta}$ and $\ell_{\theta}$ are consumption and labor supply (negative leisure) of someone with ability $\theta$. Income depends upon ability and labor supply:

$$
\begin{aligned}
Y=y\left(\theta, \ell_{\theta}\right) \text { with } y_{\theta}^{\prime} & >0 \\
y_{\ell}^{\prime} & >0 .
\end{aligned}
$$

The government cannot observe ability $\theta$, and hence cannot tax $1 t$; it only observes income, a compound of ability and labor supply. Thus, it imposes a (for expository purposes only) linear negative income tax with credit $\alpha$ and marginal tax rate $\beta$. Hence, 


$$
\alpha=\beta \int y\left(\theta, \ell_{\theta}\right) g(\theta) d \theta \text {. }
$$

Hence, the budget constraint for an individual with ability level $\theta$ is

$$
C_{\theta} \leq y\left(\theta, \ell_{\theta}\right)+\alpha-\beta y\left(\theta, \ell_{\theta}\right) .
$$

Individual maximization of (10) subject to (12) ylelds

$$
\begin{aligned}
& c_{\theta}^{*}=C_{\theta}^{*}(\alpha, \beta) \\
& \ell_{\theta}^{*}=\ell_{\theta}^{*}(\alpha, \beta) .
\end{aligned}
$$

In choosing $\alpha$ and $\beta$, the government seeks to maximize soclal welfare subject to (12) and the behavior of Individuals defined by (14). We may represent this soclal welfare function as

$$
\int G\left(U_{\theta}\left(C_{\theta}^{*}, \ell_{\theta}^{*}\right) g(\theta) d \theta\right.
$$

Characteristics of the solution include the implication that the more elastic is the supply of labor, the lower are $\alpha$ and $\beta, 1 . e .$, the larger 1s the wage elasticity of labor supply, the less progression is socially desirable.

Since the analysis of optimal indirect taxation revealed that the smaller the wage elasticity of labor supply, the less desirable is capital Income taxation, an interesting paradox occurs: a conflict is created, via the wage elasticlty of labor supply, between increasing progression 
and the taxation of capital income! If the wage elasticity of labor supply is small, substantial progression can be fustifled, but in a consumption tax, not an income tax! If the wage elasticity of labor supply is large, taxes on Interest income are desirable, and hence income taxation tends to be preferable to consumption taxation, but the amount of progression which is socially destrable is severely limited!

Our story is by now familiar: the rigorous analysis in the optimal tax theory framework of another important issue of tax policy focuses attention on econometric studies of labor supply and saving. To these we now turn. 


\section{Empirical Evidence}

Now that we have established that (estimates of) labor supply (leisure demand) and consumption (saving) elasticities are central concerns in applying optimal tax theory to tax policy, we must examine what is known empirically about these parameters. 9

I shall argue that we have made considerable progress in recent years in understanding both labor supply and consumption behavior. While we have not yet precisely pinned down the relevant elasticities so as to permit exact calculations of optimal tax formulae, I do believe some extremely important general tendencies have been well documented and they do have certain useful policy implications.

The notion that private saving is unaffected by taxes has received widespread acceptance among empirical and policy-oriented macroeconomists in the United States (see, e.g., Okun [1975]). This inference is virtually always based on evidence which is flimsy at best and dangerously misleadIng at worst - the relative constancy of the gross private saving rate in years of relatively full employment in the United States. While neither the numerator nor the demoninator of this ratio measure the economically correct concepts very well, a strong behavioral significance is attached to this reduced form relation. The best attempt to rationalize this relationship (usually termed "Denison's Law") - which to my knowledge has never been observed for any other economy - is that of David and Scadding [1974].

${ }^{9}$ I shall confine myself to estimates for the United States, both because they are much more voluminous and $I$ am much more familiar with studies based on U.S. data than their counterparts based on non-U.S. data. 
In a thought provoking reexamination of "Denison's Law," they document the continued constancy of the gross private saving rate, the constancy of the saving rate augmented to include consumer durables purchases In saving and the rental flow from durables in income, and changes in the composition of private saving between the household and business sectors. They interpret this relative constancy of the gross private saving rate as evidence that taxes - either through a reduction in private income or a reduction in the real net rate of return on capital - do not affect private saving behavior. While this argument also has been made by a large number of other economists, we shall demonstrate below that drawing such behavioral inferences from these data is not warranted. The argument they use to rationalize "Denison's Law" is that taxes and present consumption are essentially perfect substitutes; the rise in taxes is offset by an equivalent decline in current consumption. They go on to explore a variety of intriguing conjectures concerning consumer behavior.

Three basic points need to be made concerning this conjecture. First, most theories of consımer behavior relate saving to disposable income. If this is correct, the saving rate varies substantially. Second, it indeed would be surprising if consumers made this type of rational calculation vis $a$ vis the government and business sectors in terms of gross saving and income. Consumers' capital depreciates. Again, our economic theories generally relate to how consumers choose their net position. Further, except for some possible embodied technical change, it 
Is net saving that is relevant to the issue of whether taxes affect capital accumulation. The net private saving rate - net saving divided by net income - exhibits substantially more relative varfation than the gross series and can hardly be called constant, even if we confine ourselves to the postwar period. ${ }^{10}$ While depreciation series are notoriously unreliable; use of several alternative serfes based on tax, replacement cost, etc. depreclation still yields substantial variation in the net private saving rate. I take this to be a strong indictment of the structural interpretation of "Denison's Law."

Third, even if total gross income and gross saving are examined, there still may be an 1ndependent effect of real net rates of return on saving. Even if taxes and present consumption are perfect substitutes (the public sector is doing its benefit-cost analyses properly, free rider issues are ignored, etc.), the share of private wealth consumed today (publically or privately) will depend upon the net, or after-tax return to saving, whereas gross income is the flow from private wealth at the gross return. Hence, taxes decreasing the net return to saving may cause a decrease in saving. Before proceeding to a variety of estimates of saving equations, it is perhaps worthwhile to offer a brief conjecture on the apparent constancy of the saving rate. Consider two motives for saving: smoothing of consumption over the life-cycle and bequests. Further, assume bequests (broadly construed to include proviston of education as well as pure financial bequests) are luxurfes. Hence real income growth would tend to increase saving.

\footnotetext{
${ }^{10}$ If we took the broader view of saving as inclusive of human investment, use of Kendrick's [1976] data reveals still more varlability in the total saving rate, gross as well. as net.
} 
However, if saving is also positively related to the real net return on capltal, the slight decline in this rate would lead to a decrease in saving. Hence, the two effects offset one another. No doubt many other effects have been at work as well. Thus, I find it extremely difficult to give any structural or behavioral interpretation to the constancy of the gross private saving rate.

Merely pointing out some difficulties in interpretation of some data does not suffice to reject the conjecture outright; nor does it provide an alternative behavioral interpretation. Hence, we turn now to estimates of the effect of taxes on private saving, i.e., to estimates of consumption. functions.

Until quite recently, empirical studies of the effects of (tax-induced) varlations in the real after-tax rate of return on private saving were few and far between. Break [1974] notes "Unfortunately, empirical evidence on the interest elasticity of the saving rate is rare." Most such studies conclude that interest rates have only a negligible effect on consumption or saving. Musgrave and Musgrave [1974] report that "Studies of the relationshlp between saving and the rate of return differ in their conclusion. Some hold that there is a substantial negative relationship, while others attribute little weight to the rate of interest in the consumption function." Feldstein [1970] has demonstrated that studies which use the nominal (and/or before-tax) rate of return when the real (net) rate is appropriate almost certainly bias the estimated elasticity downwards by a substantial amount. While economic theory points to the real net of tax rate of return as the price determining the consumption-saving decision (with, perhaps an 
Independent effect of inflation), I know of only two studies which attempt to examine the sensitivity of consumption or saving to real net rates of return and, hence, to the interest rate effects of income taxation.

Wright [1969] includes a measure of the return on stocks and bonds in estimating consumption functions from U.S. annual time series data. His estimates imply an interest elasticity of 0.2 . This is substantially larger than the zero elasticity of "Denison's Law"! However, Wright's measure of consumption and income suffer from several deficiencies, his data refer to the period through 1958 only, and he estimates his equations in a manner which does not allow for the endogeneity of the rate of return.

I have reexamined U.S. aggregate time series data in Boskin [1977]. Using improved data on consumption, income and wealth, I have estimated consumption functions for several alternative sub-periods, definitions of the key variables, functional forms, and estimation methods. My preferred estimate is as follows:

$$
\begin{aligned}
& \text { LGCONSP }=-5.83+0.55 \text { LGDPI }+0.32 \operatorname{LGDPI}(-1)+0.72 \operatorname{LGWLTH}(-1) \\
& (1.55) \quad(0.13) \quad(0.23) \quad(0.03) \\
& -0.031 \text { LGUNEM }-2.28 \mathrm{R}-0.36 \pi \\
& (0.014) \quad \cdot(0.62) \quad(0.21) \\
& \mathrm{R}^{2}=0.99 ; \quad \mathrm{SSR}=0.0087 ; \quad \mathrm{SE}=0.021
\end{aligned}
$$

where LG refers to natural logarithms, (-1) to a one-period lag, $R$ to the estimated real net rate of return, $\pi$. to the expected rate of inflation, UNEM to the unemployment rate, WLTH to the market value of 
assets, DPI to disposable private income and CONSP to consumption. This equation is estimated by an instrumental variables procedure which uses as instruments principal components of the varlables usually deemed exogeneous in large macroeconometric models (see Amemiya [1966] and Jorgenson and Brundy [1973]). It performs quite well by conventional measures. The estimated standard error is a minute fraction of the mean value of the left-hand varlable. The estimated real net rate of return elasticity of private saving is slightly larger than 0.4 .

My other specifications yield estimated real net interest elasticities of 0.2 to 0.6 (see Boskin [1977]). While such elasticities are hardly enormous, they are much larger than those suggested by advocates of extremely high taxes on capital income. We shall return to some extremely important policy implications in our next section. For the moment, it suffices to note that saving apparently is modest1y sensitive to the taxation of capital Income.

What about labor supply? There is also a conventional wisdom that taxes do not affect Incentives to work (again, see Okun [1975]). A more detailed examination of this issue suggests that the effect of taxes on total labor supply - including hours of work, work effort and human investment - is quite difficult to estimate; we have a fairly useful set of estimates of the effects of taxes on hours of work. This effect appears to differ dramatically among alternative population subgroups. Unfortunately, we know little about the effects of taxes on effort or human investment.

The renewed interest in estimating labor supply functions in the U.S. occurs not only because of the availability of better data and improved 
estimation techniques, but because of the hotly debated issue of the desirability of a universal income guarantee or negative income tax. Obviously, the attention of both the politicians and the researcher has been on the effects of negative income taxation on the work effort of the poor, the recipients of the negative taxes. The theory of optimal taxation, of course, reveals that the potential disincentive effects of the high tax rates on the non-poor (used to finance the transfer) are at least equally important.

The concept of labor supply relevant in our context is labor supply in the envelope sense. Thus, effective labor supply reflects decisions on hours of work, human investment and effort, as well as the individual's ability. For expository convenience, suppose we can write the labor supply as the product of these variables:

$$
L S=H \cdot E \cdot A \cdot I
$$

where $H$ is hours, $E$ is effort, $A$ is ability, and $I$ is cumulative net human investment.

The optimal income tax models postulate a probability distribution of A In the population, which is given independent of taxes. $H, E$ and $I$, however, are potentially affected by income taxation.

Little is known empirically about the effects of taxes on $E$, work effort. ${ }^{11}$ The effects of taxes on $I$, human investment, are rather complex (see Boskin [1976]). There frequently has been an assumption of strong tax disincentives to human investment. For example, Schultz [1961] argues

${ }^{11}$ Since non-pecuniary benefits on the job, including less effort, presumably are a normal good, the (negative) income effect of the tax probably increases effort. 
that "Our tax laws everywhere discriminate against human capital." Certainly this has never been documented empirically. Nor do adherents to this view identify the real culprit in the situation. Is it the taxation of the returns to human investment at a positive rate? Is it the progressive rate structure of the personal income tax? Is it the failure to allow educational expense deducations? Is it the income effect of the tax combined with differential public and private marginal propensities to invest in human capital?

While the effects of the personal income tax on human capital investment depends upon all of these details, we begin by focusing on what we believe to be the single most important feature of the relation between human capital investment and the tax system, namely that the bulk of such Investments are financed out of foregone earnings which are not taxed. The fallure to appreclate this basic feature of human investment is, we believe, a source of much of the confusion on the effects of taxes on human investment. 12

For example, take on-the-job training financed by tax-free foregone earnings. In the absence of an income tax, the worker would engage in onthe-job training up to the point where the incremental investment cost just matched the present value of expected future returns. The imposition of a flat rate tax $t$ on the income from the investment reduces the net return by $(1-t)$; the instantaneous write-off (since the investment cost is tax free) reduces the tax liability by $(1-t)$ (at the margin). The

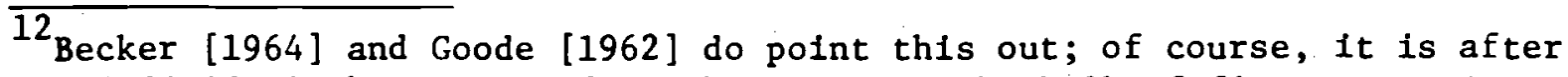
Individuals have reacted to the tax that the bulk of finance consists of foregone earnings.
} 
present value of the depreciation deduction equals the cost of the investment and if the training was a profitable investment with no tax, it is st111 profitable in the presence of the tax-free foregone earnings.

The major human capital investment cost which is not tax exempt is the direct cost of education, i.e., tuition, books and related expenses. It is these expenses which have received the most attention in the public finance literature. The argument has been that such expenditures are a valid cost of earning income and should be deductible either when made or depreclated throughout the working 1 ife. ${ }^{13}$. While true economic depreciation of educational expenses would be nondistortionary (since under true economic depreciation the differential equation describing the value of human capital is independent of the tax rate, the value of the investment would not be affected by the tax $)^{14}$ it is not the only way to achieve neutrality. Indeed, any tax which between its interest deductibility and depreciation allowances yields a deduction whose present value equals the investment cost is neutral. While $I$ would be the last to argue that capital markets work perfectly, particularly in financing human investment, a modest fraction of higher education expenses are financed by borrowing and at least the interest on this debt is deductible against future income. In analyzing when tax depreciation of educational expenses would be neutral it is fmportant to note that many students investing in education have little other income and hence would not benefit from immediate

\footnotetext{
${ }^{13}$ See Goode [1962] for a discussion of these issues. Frequently ignored is the lack of taxation on the human capital gain during education; this tax is postponed until the income stream is realized.

${ }^{14}$ See Stiglitz [1975]. Indeed, this discussion closely follows his discussion of tax depreciation of physical capital.
} 
write-off of out-of-pocket educational expenses. 15 Unless they were allowed to carry such a write-off forward for a considerable per lod, the present value of the depreciation allowance will fall short of the present value of the tax llability on the return to the investment and hence will discourage investment in education.

The progressive rate structure of the personal income tax acts in an analogous manner and not just on educational investments. Any human capital investment which increases future earnings enough to drive the taxpayer into a higher tax bracket (after accounting for income averaging provisions) may decrease the ratio of the present value of the depreciation allowance to the present value of the incremental tax liability. Investments which are profitable at the current tax rate may not be so when account is taken of the increased future tax rate.

In addition to the distortion in the amount of the investment in human capital, the tax system also alters the composition of human investment. For example, the instantaneous depreciation of foregone earnings (relative to slower economic depreciation) favors longer-lived human investments, e.g., general, rather than job specific, on-the-job training.

In summary, the current progressive rate structure of the personal income tax probably creates a disincentive to accumulate human capital; this disincentive is perhaps most severe for secondary workers in twoearner families whose incremental incomes from human investment may generate a large increase in marginal tax rates. The lack of an educational

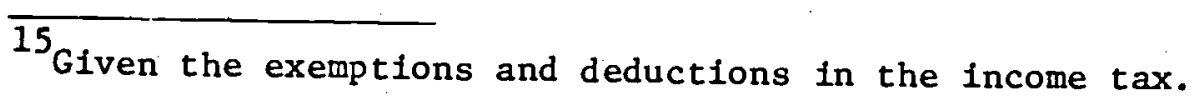


expenditure depreciation allowance probably biases investments away from education to job training. While the extent of these distortions is not yet known, the fact that the bulk of such investment is financed by taxfree foregone earnings casts doubt on the assertion that such disincentives are large.

What about tax disincentives to hours of work? A large number of empirical studies have been completed recently (see, e.g., the studies in Cain and Watts [1974], Heckman [1974], Rosen [1976], and Hurd [1976]). These studies report labor supply elasticities which differ somewhat, but as a whole they reveal the following: the hours of work of the largest group in the labor force - husbands - is not very elastic. Hurd's [1976] estimates (which in many ways are the best, accounting for numerous econometric problems) are the largest: an average elasticity of one-half; the other studies estimate less elastic hours of work for husbands. However, the hours of work of secondary workers - particularly wives and elderly persons (see Boskin [1977]), are quite sensitive to (tax-1nduced) variations in the net wage. The estimated wage elasticity of labor supply for. wives usually exceeds unity.

What then, shall we conclude about labor supply? While much more work needs to be done before we can pin down the elasticities for different groups precisely, we can conclude the following:

1) Taxes affect the hours of work of wives and elderly persons substantially (as the wage elasticity of hours of work for these groups is large);

2) Taxes do not appear to affect the hours of work of husbands (although we should be careful about extrapolating to extremely high rates) nearly as much as they do wives and elderly persons; 
3) Taxes may distort both the composition and the amount of human Investment; however, the effect on total human investment is mitigated substantially by the tax-free nature of foregone earnings, the major source of finance for human investment.

4) Virtually nothing is known about the effects of taxes on the level of effort.

With these empirical studies of labor supply and saving in mind, we turn now to a discussion of their implications for tax policy. 


\section{Implications for Tax Policy}

The theory of optimal taxation, combined with econometric evidence on labor supply and saving, has important implications for a variety of issues in tax policy. We shall discuss their implications for three features of the U.S. tax system: the income-splitting provision for twoearner families, the rate structure of the income tax, and the choice between income and consumption as the tax base. We start by dealing with piecemeal policy changes and then note their interrelation.

The theory of optimal taxation implies that, ceteris partbus, income tax rates should be higher on those population groups with the lowest labor supply elasticities. Thus, income tax rates should be higher on the primary earner in the family (usually the husband) than on the secondary earner(s).

Thus, the income-splitting provision, which allows spouses to pool their Income and to be taxed as if each earned one-half of the total, is inefficient. In making the marginal tax rate paid on the first dollar of earnings of the secondary worker equal to that paid on the last dollar of earnings of the first worker, this provision can reduce substantially the after-tax wage received by the secondary worker. It is not uncommon in middle-class fainilies in the United States for the marginal tax rate on the first dollar earned by the secondary worker in the family to reach forty percent or more; and to this must be added transportation and other costs. Combined with the non-negligible wage elasticity of the labor supply of wives (who frequently are the secondary earner in the family), this Implies a huge labor supply disincentive. Sometimes this 
takes the form of withdrawal (permanently or periodically) from the labor force.

I have estimated (see Boskin [1974]) the welfare cost of the taxInduced reallocation of the capital stock and labor force between the market and the home to exceed $\$ 20$ billion, an astounding waste of resources. 16

While the econometric evidence is not in sufficient agreement to permit an exact calculation of the optimal tax rates for primary and secondary earners, the estimates are simflar enough and sufficiently robust to conclude that the tax rates on secondary earners ought to be substantially less than those on primary earners. Clearly, abolition of the incomesplitting provision would be a major improvement; we may eventually have preclse enough estimates to propose a new set of rate schedules in which the rates differ not only by Individual income, but also by whether the Individual is the primary or secondary earner in the family.

The optimal income tax literature warns us of the danger of extremely high marginal tax rates on population groups with some elasticity to their labor supply. While the evidence for the bulk of the labor force - husbands - suggests only a small elasticity of hours of work, to this must be added any disincentives to human investment and work effort. As noted above, empirical information on these issues is rather desperately needed. My own opinton is that there is enough of an elasticity to argue against extremely high rates of tax but not so high as that frequently assumed in producing the very low rates reported in the optimal income tax 1iterature.

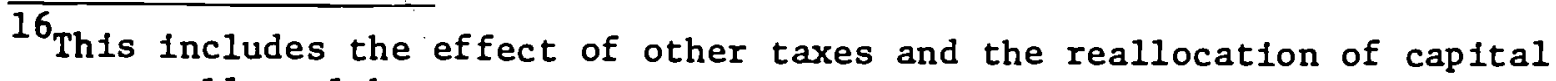
as well as labor.
} 
Since the disincentives depend heavily upon the marginal tax rates, a strong argument can be made for broadening the base of the tax and lowering the rates. ${ }^{17}$ While I do not agree that there is no justification for many of the provisions in our various taxes which reduce their bases substantial1y (e.g., taxable income in the U.S. Individual income tax is perhaps onethird of income correctly measured), one way to reduce the tax rates is to broaden the tax base. ${ }^{18}$ A second, of course, is to decrease the revenue raised by the government. The optimal income tax literature suggests that rather little public income redistribution is desirable, a striking contrast to the trends in virtually all advanced economies. This issue is deserving of a deeper analysis than I can provide here; I merely mention that I have elsewhere (Boskin and Sheshinski [1976]) suggested a possible explanation for this disparity (a relative income effect).

What does the evidence suggest as to the choice between income and consumption as the appropriate base of tax? I hope I have convinced you that saving is by no means in completely inelastic supply. Hence, a tax only on capital income is ruled out by the basic results of optimal tax theory. I also believe that between the hours of work of secondary earners and the hours, effort and human investment of primary workers that there is enough elasticity of aggregate labor supply to rule out a labor income tax as the only form of taxation, 1.e., a consumption tax alone is not optimal. However, in the U.S. (as in most other countries) capital income is taxed at much higher rates than is labor income accruing to the same individual.

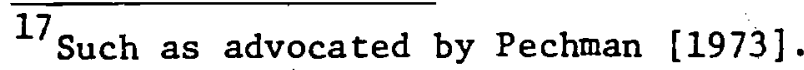

${ }^{18}$ Indeed, the flow of income into tax-free activities occurs largely because of the high marginal tax rates.
} 
The separate corporate income and property taxes, the celling on tax rates on earned income and certain other provisions make the marginal tax rate on (a large share of) income from capital much higher than that on labor Income. This has reduced saving in the U.S. by a large amount; in turn, the reduction In capital accumulation has decreased income and welfare and ralsed the return on capital relative to that on labor. Again, I have analyzed this in detail elsewhere (Boskin [1977]). My conclusion 1s that the rates of tax on capital Income should be lowered relative to those on labor income; optimal tax theory and the econometric evidence point strongly in this direction. Such policles as Integrating the corporate and personal income tax and/or reforming the taxation of individuals in the direction of a consumption tax are desirable.

Many authors have concluded that a very progressive personal income tax is desirable. The analysis and empirical results suggest that extensive progression and income taxation do not go together: the larger the wage elasticity of labor supply, cet. par, the less progression is desirable and the more desirable is the taxation of interest income; the lower this elasticity, the more progression is desirable and the more desirable is the exemption of interest income from taxation.

The three policies discussed above have an important interrelation. If we abolished income-splitting in favor of a separate, lower rate schedule for secondary earners, part of the labor supply disincentive which inhibits high marginal rates on labor income could be overcome. A more comprehensive tax base could also allow a reduction in rates which could more easily be combined with the higher rates of tax on labor income implicit in a consumption tax. The combination of the three policies - moving toward a comprehensive personal tax which largely exempted the income from 
capital and embodied a separate schedule of (lower) rates for secondary earners - would substantially improve welfare and allow a more equitable distribution of the command over resources. The potential gains from reducing these severe tax distortions in our economy are enormous. While I belleve we have more work to do before we can recomend precisely optimal policies, on many 1mportant issues, including the three discussed above, the theory and evidence are sufficiently clear in their implications to provide an important impetus to tax reform today. 


\section{REFERENCES}

Amemiya, T., "On the Use of Principal Components of Independent Variables In Two-Stage Least Squares Estimation," Int. Econ. Rev., September 1966.

Atkinson, A.B., and J.E. Stiglitz, "The Structure of Indirect Taxation and Economic Efficiency," J. Publ. Econ., 1, 1972, 97-119.

, "The Design of Tax Structure: Direct vs. Indirect Taxation," J. Pub1. Econ., 1976.

Baumo1, W., and D. Bradford, "Optimal Departures from Marginal Cost Pricing," Amer. Econ. Rev., January 1970.

Becker, G., Human Capital, Columbia University Press for NBER, 1964.

Boiteux, M., "Sur la Gestion des Monopoles Publics Astreint à l'équilibre budgétaire," Econometrica, 24, 1956, 22-40

Boskin, M.J., "Optimal Tax Treatment of the Family," Memorandum 143, Center for Research in Economic Growth, Stanford University, Stanford, Ca., 1973.

, "Efficiency Aspects of the Differential Tax Treatment of Market and Household Economic Activity," J. Publ. Econ., January 1975.

, "Notes on the Tax Treatment of Human Capital," Conference on Tax Policy, U.S. Treasury Department, 1976(a).

, "Social Security and Retirement Decisions," Econ. Ing., forthcoming, $1976(\mathrm{~b})$.

, "Taxation, Saving and the Rate of Interest," Jour. Pol. Econ., forthcoming, 1977.

Boskin, M.J., and E. Sheshinski, "Optimal Income Redistribution When Individual Welfare Depends Upon Relative Income," NBER Working Paper No. 144, 1976.

Break, G.F., "Taxation," in A. Blinder, et. al., The Economics of Public Finance, Brookings Institution, Washington, 1974.

Caln, G., and H. Watts, (eds.), Income Maintenance and Labor Supply, New York, 1974.

David, P., and J. Scadding, "Private Saving: Ultrarationality, Aggregation and 'Denison's Law'," Jour. Pol. Econ., 1974.

Diamond, P., and J. Mirrlees, "Optimal Taxation and Public Production: I and II," Amer. Econ. Rev., March and June 1971.

Dupuit, J., Troite theorique et pratique de la conduite et de la distribution des eaux, Paris, 1854. 
Edgeworth, "The Pure Theory of Taxation," Econ. J., $1897^{\circ}$

Feldstein, M., "Inflation, Specification Bias and the Impact of Interest Rates," J. Pol. Econ., November 1970.

, "The Theory of Tax Expenditures," Harvard University, mimeo, 1975.

, "The Welfare Costs of Capital Income Taxes," J. Pol. Econ., forthcoming, 1977.

Goode, R., "Educational Expenditures and the Income Tax," in S. Mushkin, ed., Economics of Higher Education, 1962.

Hahn, F.H., "On Optimum Taxation," J. Econ. Theory, 6, 1973, 96-106.

Harberger, A., "The Measurement of Waste," Amer. Econ. Rev., May 1964.

Heckman, J., "Shadow Prices, Market Wages, and Female Labor Supply," Econometrica, 1974 .

Hotelling, H., "The General Welfare in Relation to Problems of Railroad and Utility Regulation," Econometrica, 1936.

Hurd, M., "The Estimation of Labor Supply from a Truncated Sample with Taxes," IMSSS, Stanford University, 1976.

Jorgenson, D., and J. Brundy, "Consistent Efficient Estimation of Systems of Simultaneous Equations by Means of Instrumental Variables," IMSSS Technical Report No. 92, March 1973.

Kendrick, J., The Formation and Stocks of Total Capital, NBER, forthcoming, 1976.

Mirrlees, J.A., "An Exploration in the Theory of Optimum Income Taxation, Rev. Econ. Stud., 38, 1971, 175-208.

Mohring, H., "The Peak-Load Problem Under Increasing Returns and Pricing Constraints," Amer. Econ. Rev., 1973.

Musgrave, R., and P. Musgrave, Public Finance in Theory and Practice, McGrawHill, 1973.

Okun, A., Equality vs. Efficiency: The Big Trade-0ff, 1979.

Pechman, J., Federal Tax Policy, rev. ed., Brookings, 1971.

Pigou, A.C., A Study in Public Finance, Macmillan, London (3rd edition), 1947, lst edition, 1928.

Ramsey, F.P., "A Contribution to the Theory of Taxation, Econ. J., 37, 1927, 47-61.

Rosen, H., "The Impact of U.S. Tax Laws on the Labor Supply of Married Women," Rev. Econ. and Stat., 1976. 
Sandmo, A., "Optimal Taxation - An Introduction to the Literature," J. Publ. Econ., 1976.

Schultz, T. W., "Investment in Human Capital," Amer. Econ. Rev., 51, March 1961.

Stern, N., "On the Specification of Models of Optimum Income Taxation," J. Publ. Econ., 1976.

Stiglitz, J., "The Corporation Tax," Tech. Report No. 162, IMSSS, Stanford University, 1975.

Wright, C., "Saving and the Rate of Interest," in A. Harberger and M. Bailey, eds., The Taxation of Income from Capital, Brookings, 1969. 